\title{
Configurational theory and practices of firms employing multiple pricing policies: assessing effective and ineffective pricing recipes in multiple firm contexts
}

\author{
Stephan M. Liozu ${ }^{1}$. Sven Feurer ${ }^{2} \cdot$ Andreas Hinterhuber $^{3} \cdot$ Arch Woodside $^{4}$
}

Received: 20 May 2020 / Accepted: 25 November 2020 / Published online: 13 March 2021

(c) The Author(s), under exclusive licence to Springer Nature Limited 2021

\begin{abstract}
This study examines the presence and impact of complex alternative organizational configurations of pricing on firm performance. The dataset is from a survey of company owners and company CEOs, of which a subsample was used previously and analyzed with multiple regression analysis. Analyzing an enlarged dataset that includes new data using fuzzy-set qualitative comparative analysis (fsQCA) supports the perspective that multiple price policy paths are identifiable for indicating high performance for different firm operational contexts. By applying the perspective of complex interdependences of specific pricing activities and specific organizational configurations related to pricing, this study offers a nuanced contribution to marketing theory. To practicing managers, this study offers guidance for adopting specific configurations of pricing policies in specific contexts for achieving high firm performance as well as guidance on which configurations indicate negative firm performance outcomes.
\end{abstract}

Keywords Championing · Capabilities · Collective mindfulness · Pricing $\cdot$ Firm performance

\section{Introduction}

Most managers and researchers will agree that pricing products effectively is a complex endeavor. Economists and practitioners long recognize the complexity of developing the right pricing strategy (Oxenfeldt 1973), and managers are struggling to master this task to the extent that many appear to have "thrown in the towel" on pricing (Lancioni 2005, p. 111). In the academic literature, this complexity appears to

Stephan M. Liozu

sliozu@case.edu

Sven Feurer

sven.feurer@kit.edu

Andreas Hinterhuber

andreas.hinterhuber@unive.it

Arch Woodside

arch.woodside@bc.edu

1 Case Western Reserve University, Cleveland, OH, USA

2 Karlsruhe Institute of Technology (KIT), Karlsruhe, Germany

3 Università Ca Foscari, Venezia, Italy

4 Yonsei University, Seoul, Republic of South Korea reside mainly in tough competitive contexts and the seemingly irrational consumer responses to prices and pricing tactics that depart from the predictions of standard economic theory (e.g., role of reference prices, price partitioning, and price fairness). At the same time, the complexity of managing the pricing decision process within the firm receives far less attention in the relevant literature. For example, managers may benefit from exploring the following issues.

- estimating which strategies in pricing capabilities enable firms to establish superior pricing processes (Dutta et al. 2003)

- identifying which organizational structures and contexts of pricing authority are favorable versus unfavorable to firm performance (Homburg et al. 2012)

- learning to what extent cost-based, competitor-based, or customer value-based information should underlie the pricing decision (Ingenbleek et al. 2010, 2013)

- learning when versus whether or not the pricing decision process characterizes rational or intuitive information processing (Feurer et al. 2018; Liozu and Hinterhuber 2013a). 
The extent to which answers to these decisions lead to the achievement of the firm's pricing objectives likely depends on firm-related, product-related, and market environmental contextual factors (Homburg et al. 2012; Ingenbleek et al. 2003). Prior research mostly provides insights into isolated drivers of pricing performance and does not illuminate their potentially complex interplay. Although this perspective is relevant probably most empirical research, a more holistic approach accounting for these complex relationships likely leads to important insights and more nuanced theoretical and managerial implications.

To fill this literature gap, we adopt a complexity theoretical perspective (Urry 2005; Woodside 2014, 2015) to deepen understanding how a multitude of combinations of different antecedent conditions may affect firms' performance outcomes. Complexity theory recognizes that the realities in which firms and their managers operate and make pricing decisions are complex, "whether we like it or not" (Gummesson 2008, p. 16). Gummesson (2008) emphasizes that complex interactions between variables exist, that a nearly unlimited number of unique situations occur, that change is a natural state of affairs, that processes are iterative rather than linear. Gummesson (2008) calls for researchers to account for this complexity in their cause and effect models.

Complexity theory also builds on the notion that relationships between variables are often asymmetric (e.g., Fiss 2011; Ragin 2008; Wu et al. 2014). Asymmetry of relationships in our focal context means that, for instance, high value-based pricing may associate with high firm performance, but this finding does not necessarily imply that low value-based pricing associates with low firm performance. Moreover, equifinality is likely to occur (Ragin 2000), meaning that both low and high value-based pricing may-in combination with a specific set of other antecedent conditions-lead to the same high (or low) firm performance. Similar to a cake recipe, while one single antecedent condition (ingredient) such as high value-based pricing may be necessary for producing high firm performance (great taste), this single antecedent condition is unlikely to be sufficient for achieving this outcome (Feurer et al. 2016; Wu et al. 2014). Rather, several configurations of antecedent conditions may exist, all of which are sufficient for achieving high firm performance, just like different recipes are available for a great tasting cake outcome.

Our principal research questions are whether or complex configurations of antecedent conditions occur and, if yes, which predict high firms' performance, if any. To answer these questions, the study here draws on complexity theory to develop an integrative framework of the pricing task that assumes a complex interplay of conditions relating to not only pricing inputs, the pricing process, but also firm-, product- and market-environment-related contextual factors. A "condition" is a broad or narrow point estimate for a variable (e.g., a price point in the top quintile is a price condition for the variable, price; a B-to-B firm is a condition identifying the firm. The principal theoretical perspective in the present study is that high firm performance is achievable if specific configurations of inputs, processes, and context factors fit together well. The study analyzes the data using a case configurational analysis of conditions. The data are from 557 CEOs and business owners. The study applies fuzzy-set qualitative comparative analysis (fsQCA), a still relatively new, case-based analytical technique appropriate for complex configuration analysis (Fiss 2011; Ordanini et al. 2014; Ragin 2009). In part, some of the data have been analyzed and published with traditional, covariance-based methods for symmetric variable-directional relationships via null hypothesis significant tests (NHSTs). The present study also includes new, previously unpublished data and casebased theory and asymmetric, configurational case-based, conditional, specific outcome, odds-ratio tests.

\section{Conceptual framework}

What follows is an integrated framework of the pricing task (Fig. 1). We briefly review the relevant literature and sort it into two major areas: pricing-setting effectiveness and its contextual factors. The main goal is to highlight potential "special cases" where effective pricing may require unique combinations of antecedent conditions. Unlike prior research, our framework builds on the two core ideas of fit and configuration: fit implies examining elements with respect to each other as opposed to examining them individually (Venkatraman 1989); configuration implies equifinality in that multiple antecedent conditions can lead to the same outcome (Woodside 2015).

Two issues are notable with regard to our conceptual framework. First, even though the framework is integrating in that it covers all broad aspects of price-setting effectiveness (pricing input, pricing process, pricing outcomes) and important contextual factors (firm, product, market environmental characteristics), we do not claim to be comprehensive in the specific variables selected. The variables included derive from our literature review of the studies we found most relevant and insightful for better understanding the complexity of the pricing task. Second, the dataset we analyze later does not include all variables that appear in our framework (in Fig. 1, the variables considered in our empirical analysis are in bold type). Thus, the remaining variables, including those not explicitly stated, extend our framework for investigation in future research. 
Fig. 1 Conceptual framework. Note The present study examines variables names in bold. The remaining variables are possible extensions that future research may investigate

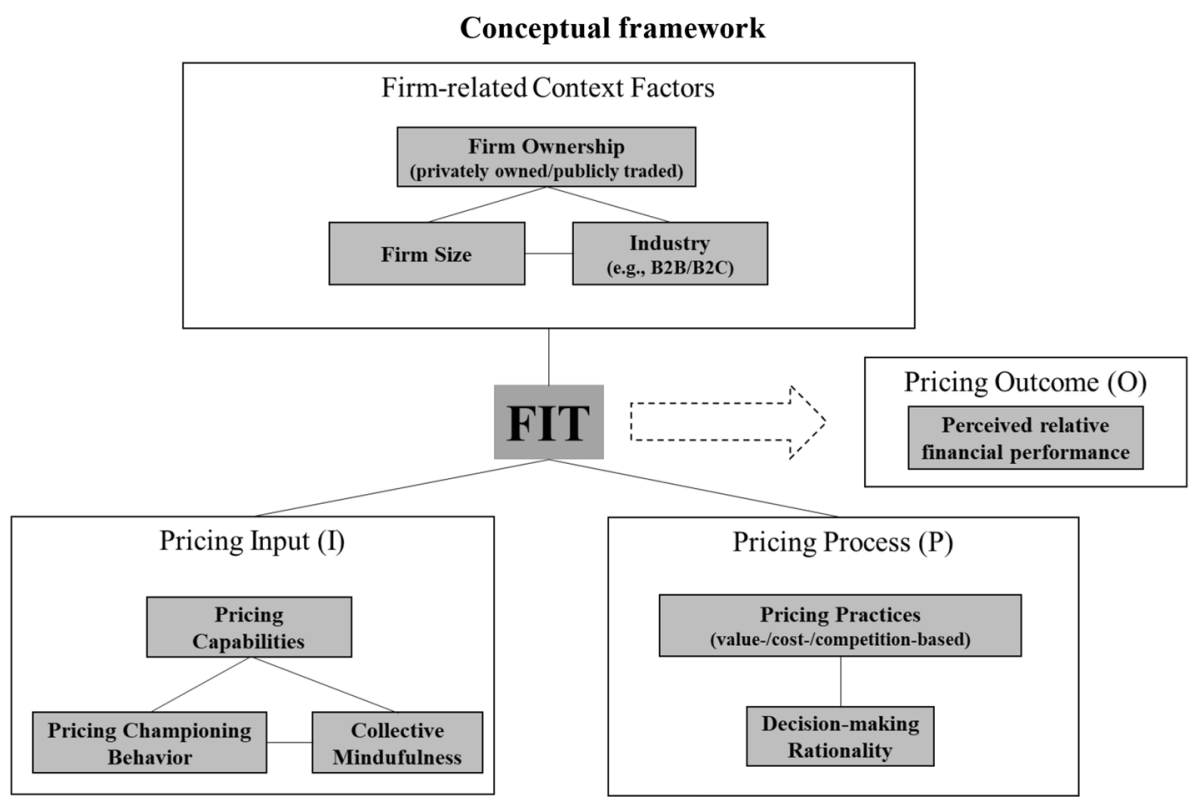

\section{Price-setting effectiveness}

We begin by employing an input-process-outcome (IPO) model of price-setting effectiveness in which organizational inputs enable specific price-setting processes, which in turn affect pricing outcomes. IPO models Prior literature criticizes are overly simplistic and deficient because of the prevalence of assuming a linear progression of main effects from one category to the next, neglecting potential feedback loops, and potential interactions between the categories (Ilgen et al. 2005). Our integrating framework of fit does not imply an indirect effect of pricing inputs on pricing outcomes through pricing processes, as the absence of a causal path between the three concepts (Fig. 1) reflects. Furthermore, the method we apply (fsQCA) is highly interactive, intended to identify distinct sets of antecedent conditions that all predict high firm performance. As such, the "I" and "P" of the IPO model both represent antecedent conditions, and the "O" represents possible outcome conditions.

\section{Pricing input}

Pricing capabilities Dutta and his co-authors (Dutta et al. 2002, 2003) were the first to emphasize that establishing superior pricing processes allows firms to appropriate the value they create, which ultimately leads to a competitive advantage. This insight is important because managers often believe that appropriating value is not much of an issue after successfully creating the perception of high value (Dutta et al. 2002). Also, conventional marketing-textbook knowledge suggests that pricing is the marketing-mix instrument that does not require spending money. Much to the contrary, these authors emphasize that investments in resources, routines, and skills (e.g., hiring and training pricing experts; adding software and hardware systems to track prices, and so on; marketing the pricing strategy internally) are necessary to develop a price-setting capability. Pricing capabilities differ across firms and have a strong effect on firm performance (Liozu and Hinterhuber 2014).

Pricing championing behaviors A further element is the behavior of the CEO with respect to pricing. In most firms, pricing is left largely to individual sales managers. In a few firms, CEOs themselves exercise a strong influence on pricing, providing direction, support, and leadership: CEO championing of pricing has a strong impact on firm performance (Liozu and Hinterhuber 2013a). Thus, we consider pricing championing behavior to be an input in the pricing task.

Pricing authority and pricing team design A central question about the pricing task is who should participate. Research emphasizes that firms share pricing authority across different functions (Homburg et al. 2012; Verhoef and Leeflang 2009). Notably, Homburg et al. (2012) examine how firms organize their pricing authority. They distinguish between vertical differentiation (the extent to which pricing authority is delegated from central management to salespeople) and horizontal dispersion (the extent to which firms spread influence over strategic pricing issues across sales, marketing, and finance). They find an inverted U-shaped effect of vertical delegation and a positive effect of horizontal dispersion on pricing performance. Moreover, anecdotal evidence suggests that firms establish pricing teams to master the complexity of the pricing strategy task (e.g., Aeppel 2002), raising the question of pricing team design. Recent research examines characteristics of the pricing team (e.g., pricing team size, experience, autonomy, functional 
diversity) and how these enable the team to develop pricing strategies for innovations (Feurer et al. 2018). Feurer et al. (2018) identify stability and experience as important design variables in this regard.

\section{Pricing process}

Pricing practices Pricing practices are "the set of activities executed by an organization's managers that lead to a price decision" (Ingenbleek et al. 2003, p. 290). Extant research makes an important distinction about which information should inform the pricing task (Ingenbleek et al. 2003, 2010, 2013; Ingenbleek and van der Lans 2013). These studies differentiate between prices based on customer value, prices based on costs such as cost-plus pricing, and prices based on competitor prices. Current research nearly universally agrees that value-based pricing increases firm performance (Ingenbleek 2007; Shapiro and Varian 1998) and is silent on counterexamples. Although Ingenbleek et al. (2013, p. 560) emphasize that all pricing decisions should be, to some extent, based on all three sources of information, they conclude that the effect of value-based pricing on market performance and price level is "unambiguously positive." And, yet, numerous surveys of providers of professional services-specifically, of law firms-indicate that firms using cost-based pricing report generally higher profits than firms using value-based pricing or other approaches not based on hourly rates (Seeger and Clay 2016). This is one indication that value-based pricing is an insufficient condition for higher profits, and that pricing approaches generally considered less than optimal can increase firm performance under a specific set of conditions.

Collective mindfulness Mindfulness is about being alert as well as about processing information in an active manner (Langer 1989). Weick et al. (1999) expand the dimension of individual mindfulness to address entire organizations or collective entities. Being mindful has been described as being open to new information and welcoming different opinions and multiple interpretations (Langer 1989, 1997), leading to "a rich awareness of discriminatory detail and a capacity for action" (Weick et al. 1999, p. 37). Collective mindfulness, for example in pricing teams, should be helpful in pricing given the sensitivity of the issue (e.g., small changes in price may have a strong and short-term impact on performance). Liozu and Hinterhuber (2013a) find collective mindfulness to be positively related to pricing capabilities, pricing championing behavior, and firm performance.

Rationality/intuition Rationality pertains to conscious information processing; intuition is a more subconscious way of processing information without logical inference or analytical methods (Evans 2008). The literature appears to converge toward the notion that rationality and intuition are not extremes of a continuum but the need to conceptualize is apparent as two distinct modes of processing information are applicable to a greater or lesser extent (e.g., Elbanna and Child 2007). The question of the (dys)functionality of rationality versus intuition has been asked in many domains, including strategy (e.g., Miller and Ireland 2005; SadlerSmith and Shefy 2004) and innovation management (e.g., Eling et al. 2014, 2015). In pricing, recent research indicates that rationality in pricing processes is generally positive, but high levels of intuition in the development of a pricing strategy for an innovation can lead to superior pricing outcomes compared with low levels in the case for a radical (but not incremental) innovation (Feurer et al. 2018).

Political behavior Along with rationality and intuition, political behavior is a third key aspect of strategic decision processes (Elbanna and Child 2007). Political behavior occurs when "decision makers have different goals, forming alliances to achieve their goals in which the preferences of the most powerful prevail" (Elbanna and Child 2007, p. 434). Pricing research has yet to examine the effects and occurrence of political behavior in pricing processes: however, given the cross-functional nature of pricing, it is perhaps not surprising that anecdotal evidence points towards political behavior aimed at gaining influence in the pricing decision-making process (Smith 1995).

Pricing-process-related variables include the following elements: the primary pricing orientation of the firm-cost, competition, and value - which has a strong and direct effect on firm performance (Ingenbleek 2007). We also include decision-making rationality (Miller 1987), or the extent to which decisions in firms are planned as opposed to intuitive.

\section{Outcomes}

Pricing decision A critical outcome of the pricing decision process is the actual pricing decisions made. These may be strategic or tactical. For an innovation, the literature considers skimming or penetration pricing (Dean 1969) as generic pricing strategies that firms apply frequently in practice. However, the decision about whether or not to employ either of these strategies is not straightforward, and much remains about their usefulness (Hultink et al. 1998, 2000; Lowe and Alpert 2010). Next, managers need to set the price level and actual price points, keeping in mind potential behavioral aspects of how they are perceived by customers, many of which are not limited to business-to-consumer (B2C) markets (Hinterhuber 2015). Again, different contextual factors may require a different set of strategic and tactical pricing decisions.

Pricing decision effectiveness When pricing their products, firms will have specific goals in mind. These typically relate to either market performance or financial performance, on either the product or the firm (strategic business unit) level. Thus, the effectiveness of a pricing strategy is 
typically assessed by managers based on an evaluation of whether these goals were achieved (Feurer et al. 2018). Authors have examined a variety of different pricing outcomes, ideally drawing on independent financial data such as return on assets (Homburg et al. 2012). Perceptual measures of financial and market performance are also frequently used because independent financial data are typically not available on the project level (e.g., Feurer et al. 2018; Ingenbleek et al. 2013).

\section{Contextual factors}

A large body of literature highlights the importance of contingency factors in organizational decision making. For instance, Tushman and Nadler (1978) suggest a contingency perspective of organizational design such that "the structure of an organization should match or fit characteristics of certain variables both inside and outside the organizational system" (p. 613); thus, contingency factors may affect which organizational aspects of the pricing task prove effective (Feurer et al. 2018; Homburg et al. 2012). Similarly, contingency theoretic accounts of strategic decision making posit that strategic decision processes (in the focal case, the development of a pricing strategy; Feurer et al. 2018) are effective depending on various decision-specific as well as external environmental and internal firm characteristics (e.g., Elbanna and Child 2007).

The following discussion considers contextual factors relevant for some set of firms for the price-setting task and the extent to which pricing inputs and processes lead to the desired outcomes. Therefore, the combination of input and process variables needs to fit the combination of contingency variables at hand. Prior empirical literature typically examines these variables as control variables even though some were explicitly identified as important moderators. In fact, all-too-special cases may have been identified as outliers (which do not exist in fsQCA) by correlational research (Woodside et al. 2013).

\section{Firm characteristics}

Firm size Firm size is a key factor, as pricing in small and medium-sized firms is less formalized than in large firms (Carson et al. 1998). One possible effect may be that in large firms, managers involved in the pricing task are less likely to rely on their intuition given that all steps in the pricing decision process are documented and they will be held accountable for their decisions based on this documentation and their ability to reach the outcomes.

Industry type The industry type is an important factor because business-to-business (B2B) pricing is fundamentally different from B2C pricing, for which value quantification is a differentiating characteristic (Hinterhuber 2017).
Value quantification in B2B is frequently the result of procurement managers demanding the translation of offer characteristics into monetary, customer-specific benefits (Eggert et al. 2018). It is therefore plausible that value-based pricing is more beneficial for firm performance in B2B than in B2C.

Firm ownership Firm ownership influences pricing activities. Price changes immediately affect firm performance. Building pricing capabilities, transforming an organization to excel in pricing, however, requires substantial time (Liozu 2015a). Given the pressure to deliver short-term results, it is reasonable to assume that organizational initiatives to improve performance via pricing are more prevalent in privately owned than in publicly traded companies.

\section{Product type/characteristics}

Products versus services The different nature of services (e.g., its relative intangibility) may alter the nature of the pricing task (Docters et al. 2010) and thus the conditions rendering the pricing task effective. For example, surveys among law firm indicate that firms using cost-based pricing report generally higher profits than firms using valuebased pricing or other approaches not based on hourly rates (Seeger and Clay 2016). Moreover, service industries "are typically characterized by heterogeneity in consumers' valuation and usage of the service, resale constraints, and a focus on price as the service's key attribute" (Lambrecht et al. 2012, p. 2012). Consequently, service industries may require the development of rather complex pricing schemes (e.g., nonlinear pricing) or pricing policies (e.g., dynamic pricing), both of which are specifically used to price-discriminate in service industries where offers are nearly identical (e.g., subscription services).

Product innovativeness The task of pricing innovations is special because "the complexity of pricing is perhaps nowhere felt harder than in this situation" (Ingenbleek et al. 2003, p. 290). Product innovativeness refers to the newness of the innovation (i.e., incrementally or radically new). Although myriad definitions and conceptualizations exist (see Kleinschmidt and Cooper 1991), in this paper we characterize radical innovations as those that "shift market structures, represent new technologies, require consumer learning, and induce behavior changes" (Urban et al. 1996, p. 47). Pricing radically innovative products may be especially challenging given that pricing strategies are usually developed under great uncertainty about demand, costs, and competition (Dean 1969; Dutta et al. 2002; Hoeffler 2003). Thus, automated decision rules based on established products rarely apply (Monroe and Della Bitta 1978; Zbaracki and Bergen 2010). As Feurer et al. (2018) demonstrate, product innovativeness determines to what extent pricing team characteristics enable a suitable mode of information processing. 
Product advantage Product advantage relates to the compared superiority of an innovation to competing products (Gatignon and Xuereb 2016). Ingenbleek et al. (2013) as well as Ingenbleek et al. (2003) demonstrate that the effectiveness of pricing practices (value-, cost-, competitionbased) is contingent on the level of product advantage. One finding (among others) is that value-informed pricing for products with high product advantage leads to higher prices.

Spare parts Spare parts are another potentially special case of interest. For many original equipment manufacturers, the aftermarket business contributes greatly to overall profits. Pricing spare parts may be special simply because some such firms manage thousands of different spare parts (Gallagher et al. 2005). It becomes apparent that, for example, pricing each spare part systematically on the basis of each customer's value is a tough task (which in many cases could, nevertheless, greatly improve profitability). Therefore, the pricing task and the conditions rendering it effective likely deviate from more conventional cases.

\section{Market-environmental characteristics}

Market dynamism, environmental turbulence, competitive intensity, and customer price sensitivity relate to the environmental uncertainty under which organizational decisions are made. Price sensitivity refers to the extent to which customers focus on prices in choosing their suppliers (Homburg et al. 2012). These characteristics are typically used to describe industries, even though all industries may experience more or less uncertain conditions at some point (Calantone et al. 2003). Specifically, uncertain environments may call for different organizational structures (Galbraith 1974). For example, different levels of price-related market dynamism call for different levels of horizontal dispersion of pricing authority (Homburg et al. 2012). Moreover, in highly competitive markets, information about competitor prices may become outdated very quickly, with potential effects on which pricing practice is effective. Consequently, Ingenbleek et al. (2013) hypothesize and find that cost-informed pricing contributes more to new product market performance if competitive intensity (and product advantage) is high. Last, Feurer et al. (2018) treat product innovativeness as an indicator of environmental uncertainty, making it an important contingency factor in whether rational or intuitive forms of information processing lead to the innovation's financial performance.

\section{Preliminary conclusion}

Above, we provided a literature review that motivates key variables that may affect pricing outcomes. At this point, it becomes easily conceivable that distinct combinations of contingency variables-say, when a small firm's task is to price a radically innovative service-likely require a unique combination of pricing inputs and pricing processes, reinforcing the fit argument on which we base our analysis. Our proposition is that different combinations of antecedent conditions may lead to favorable pricing outcomes, such as firm performance, if only these antecedent conditions fit together. In what follows, we test our proposition using fsQCA.

\section{Method}

\section{Data collection}

A cross-sectional self-administered electronic survey was emailed to 7897 active members of the Young Presidents Organization International (YPO), a for-profit association of 18,000 business owner/executive members in over 100 countries. YPO has strict eligibility criteria for active members: age, title (CEO, owner, top executive), enterprise value, number of staff, and yearly sales. Of the 7897 surveys emailed to targeted respondents, 376 could not be delivered. 902 were completed (partially or fully), for a response rate of $12 \%$, consistent with prior research projects focusing on top executives (Simsek et al. 2010). The total number of analyzable surveys was 557 after three follow-ups were sent in the second, fourth, and seventh weeks after the initial survey launch.

To test for potential nonresponse bias (Armstrong and Overton 1977), we performed chi-square tests to compare demographic characteristics and assessed variations in data received from early versus late responders. The results indicate no significant differences, which suggests that nonresponse bias is not a problem in the dataset.

Eighty percent of the firms in our study were identified by respondents as manufacturing or service firms, and the rest were classified as retail/distribution firms. Over half $(61 \%)$ were B2B versus B2C firms. About $11 \%$ were publicly traded versus $87 \%$ privately owned. Seventythree percent of respondents indicated that they owned the firm. Half (50\%) had fewer than 250 employees; $22 \%$ had 251 to $500 ; 13 \%$ had 501 to 1,000 ; and $15 \%$ had more than 1,000 (including 3\% with over 10,000 employees). Fifty-three percent reported the age of their firm as more than 10 but less than 50 years old. The firms of $34 \%$ had existed for longer than 50 years. Business management was reported as the educational focus of $48 \%$ of respondents; $20 \%$ had technical, industrial, or engineering backgrounds; $17 \%$ finance and accounting; and $14 \%$ sales and marketing. Sixty percent of the firms were headquartered in North America, $13 \%$ in Europe, $11 \%$ in Asia/Pacific, $8 \%$ in the Middle East, and 7\% in Latin America. The data include a subset of variables discussed in the conceptual framework (Fig. 1): pricing championing behavior, pricing 
capabilities, collective mindfulness, decision-making rationality, firm performance, firm size, industry type, and firm ownership.

\section{Measurement issues}

The latent variables (pricing championing behavior, pricing capabilities, collective mindfulness, decision-making rationality, firm performance) were all measured using 7-point multi-item scales. Importantly, because our sample consisted of numerous privately owned organizations for which objective performance data are not available or sharable, we relied on a perceptual measure of firm performance. This may raise the question of a potential common method bias, as the antecedent conditions and the outcome condition were reported by the same person (Podsakoff et al. 2003). However, we again note that our main proposition and consequential analysis are highly interactive (i.e., we are not interested in a main effect on one particular predictor variable on firm performance). Given that common method variance can only deflate interaction effects (Siemsen et al. 2010), we believe that common method bias is largely not an issue in our study. Appendix 1 summarizes the measurement of the latent constructs.

Firm size (number of employees), industry type (B2B/ B2C), and firm ownership (privately owned/publicly traded) were measured using simple single-item scales. Appendix 2 shows bivariate correlations and discriminant validity.

\section{Calibration of variables into fuzzy-set scores}

We calibrated all variables into fuzzy-set scores between 0 (full nonmembership) and 1 (full membership) to specify the degree of set membership for each case. A membership score of 0.50 indicates the maximum ambiguity score between nonmembership and membership (Ragin 2008). Consequently, missing values were also scored 0.50 . The calibration was done utilizing a logarithmic function subroutine of fs/QCA 2.5 such that the median original score would translate into a 0.50 fuzzy-set score (maximum ambiguity) and the bottom and top deciles of the original score would translate into a score fully out of the set and fully in the set, respectively.

We calibrated the variable relative firm performance into a set high firm performance such that members fully in the set are outperforming the competition and members fully out of the set are performing poorer than the competition. The calibration for the antecedent conditions was performed similarly. A summary of the fuzzy-set coding schemes appears in Table 1.

\section{Fuzzy-set qualitative comparative analysis}

We analyze the data using fs/QCA 2.5. FsQCA "performs a systematic cross-case analysis that models relations among variables in terms of set membership and uses Boolean algebra to identify configurations that reflect the necessary and sufficient conditions for an outcome of interest" (Ordanini et al. 2014, p. 137). The basic functioning of fsQCA is described in detail elsewhere (e.g., Feurer et al. 2016; Fiss 2011; Ragin 2008). In brief, fsQCA first defines the property space by constructing a truth table, which consists of all possible configurations of drivers of an outcome (Ordanini et al. 2014). In our case, the drivers are decision rationality, value-based pricing, competitionbased pricing, cost-based pricing, pricing capabilities, pricing championing behavior, collective mindfulness, firm ownership, industry type, and firm size, and the outcome is relative firm performance. Since fsQCA grounds on the concept of set membership, fuzzy-set scores rather than original variable values are used, based on the coding scheme outlined above (Table 1). Consequently, each case belongs to a specific set (e.g., high rationality) to a certain degree, including the outcome set (the outcome set is high firm performance, but we run a separate analysis to investigate $\sim$ high firm performance ${ }^{1}$ to account for potential asymmetry in relations). Boolean algebra rules are then used to build membership scores for entire configurations (e.g., high rationality highly value-based large firm). We use a frequency threshold of 2 to classify specific configurations of antecedent conditions that arise more than twice as empirically relevant.

Next, configurations of antecedents that are subsets of the outcome set are separated from those that are not, based on establishing a consistency threshold (Ragin 2005). A high consistency threshold ensures that a specific configuration of antecedent conditions is sufficient to explain the outcome condition, akin to significance in statistical hypothesis testing (Ragin 2005, 2009). We used a high consistency threshold of 0.85, as recommended (Ragin 2005, 2009).

The next step is logical reduction to remove redundant configurations (e.g., the two hypothetical configurationshigh rationality highly value-based large firm and high rationality highly value-based $\sim$ large firm-are reduced to simply high rationality highly value-based because firm size is apparently irrelevant for explaining the outcome). Last, fsQCA calculates the coverage for the final configurations of antecedent conditions. Akin to effect size in statistical hypothesis testing, coverage is the extent to which a configuration of antecedents accounts for high scores of the outcome set (Feurer et al. 2016; Ragin 2008).

\footnotetext{
1 The tilde " $~ "$ is used to indicate the negation of a condition (mathematically, $\sim$ high firm performance $=1-$ high firm performance).
} 
Table 1 Fuzzy-set coding schemes

\begin{tabular}{|c|c|c|c|c|}
\hline Original variable name & Set & Original score & Fuzzy-set score & Variable label for fuzzy-set score \\
\hline \multirow[t]{3}{*}{ Relative firm performance } & \multirow[t]{3}{*}{ High firm performance } & 3.67 & 0.10 & Full nonmembership \\
\hline & & 5.33 & 0.50 & Maximum ambiguity \\
\hline & & 7.00 & 0.90 & Full membership \\
\hline \multirow[t]{3}{*}{ Decision rationality } & \multirow[t]{3}{*}{ High rationality } & 1.00 & 0.10 & Full nonmembership \\
\hline & & 2.67 & 0.50 & Maximum ambiguity \\
\hline & & 5.33 & 0.90 & Full membership \\
\hline \multirow[t]{3}{*}{ Value-based pricing } & \multirow[t]{3}{*}{ Highly value-based } & 3.80 & 0.10 & Full nonmembership \\
\hline & & 5.80 & 0.50 & Maximum ambiguity \\
\hline & & 7.00 & 0.90 & Full membership \\
\hline \multirow[t]{3}{*}{ Competition-based pricing } & \multirow[t]{3}{*}{ Highly competition-based } & 3.83 & 0.10 & Full nonmembership \\
\hline & & 5.83 & 0.50 & Maximum ambiguity \\
\hline & & 7.00 & 0.90 & Full membership \\
\hline \multirow[t]{3}{*}{ Cost-based pricing } & \multirow[t]{3}{*}{ Highly cost-based } & 3.60 & 0.10 & Full nonmembership \\
\hline & & 5.40 & 0.50 & Maximum ambiguity \\
\hline & & 6.60 & 0.90 & Full membership \\
\hline \multirow[t]{3}{*}{ Pricing capabilities } & \multirow[t]{3}{*}{ High pricing capabilities } & 2.25 & 0.10 & Full nonmembership \\
\hline & & 4.00 & 0.50 & Maximum ambiguity \\
\hline & & 5.50 & 0.90 & Full membership \\
\hline \multirow[t]{3}{*}{ Pricing championing behavior } & \multirow[t]{3}{*}{ High championing behavior } & 4.00 & 0.10 & Full nonmembership \\
\hline & & 5.75 & 0.50 & Maximum ambiguity \\
\hline & & 6.75 & 0.90 & Full membership \\
\hline \multirow[t]{3}{*}{ Collective mindfulness } & \multirow[t]{3}{*}{ High mindfulness } & 5.00 & 0.10 & Full nonmembership \\
\hline & & 6.10 & 0.50 & Maximum ambiguity \\
\hline & & 6.86 & 0.90 & Full membership \\
\hline \multirow[t]{4}{*}{ Industry } & \multirow[t]{4}{*}{$\mathrm{B} 2 \mathrm{~B}$} & $\mathrm{~B} 2 \mathrm{C}$ & 0.10 & Full nonmembership \\
\hline & & Both & 0.50 & Maximum ambiguity \\
\hline & & Unsure & 0.50 & Maximum ambiguity \\
\hline & & B2B & 0.90 & Full membership \\
\hline \multirow[t]{4}{*}{ Firm ownership } & \multirow[t]{4}{*}{ Publicly traded } & Privately & 0.10 & Full nonmembership \\
\hline & & Both & 0.50 & Maximum ambiguity \\
\hline & & Unsure & 0.50 & Maximum ambiguity \\
\hline & & Publicly & 0.90 & Full membership \\
\hline \multirow[t]{3}{*}{ Firm size } & \multirow[t]{3}{*}{ Large firm } & $<250$ & 0.10 & Full nonmembership \\
\hline & & $251-500$ & 0.50 & Maximum ambiguity \\
\hline & & $1001-10,000$ & 0.90 & Full membership \\
\hline
\end{tabular}

\section{Results}

\section{Configurations of antecedent conditions that are sufficient for high firm performance}

The results of the analysis are shown in Table 2. In Table 2, black circles " $\bigcirc$ " indicate the presence of antecedent conditions, and white circles " $O$ " indicate the absence or negation of antecedent conditions. The blank cells represent ambiguous or "don't care" conditions.
We receive 11 distinct configurations of antecedent conditions that are all sufficient for explaining high firm performance. However, most single antecedent conditions are necessary for explaining firm performance except B2B, indicated by a in each configuration. Hence, at least in our study and analysis, B2B can be interpreted as necessary for high firm performance. With all other antecedent conditions, however, the picture is less clear. For example, high valuebased pricing is not necessary for explaining high firm performance, as it is included in 7/11 configurations, but three 
Table 2 Configurations of antecedent conditions sufficient for high firm performance

\begin{tabular}{|c|c|c|c|c|c|c|c|c|c|c|c|c|c|c|c|}
\hline \multirow{2}{*}{$\begin{array}{l}\text { Configuration } \\
\text { no. }\end{array}$} & \multicolumn{10}{|c|}{ Antecedent conditions } & \multicolumn{2}{|c|}{ Coverage } & \multirow{2}{*}{$\begin{array}{l}\text { Con- } \\
\text { sistency }\end{array}$} & \multicolumn{2}{|c|}{ Overall solution } \\
\hline & $\begin{array}{l}\text { High } \\
\text { rational- } \\
\text { ity }\end{array}$ & $\begin{array}{l}\text { Highly } \\
\text { value- } \\
\text { based }\end{array}$ & $\begin{array}{l}\text { Highly } \\
\text { compe- } \\
\text { tition- } \\
\text { based }\end{array}$ & $\begin{array}{l}\text { Highly } \\
\text { cost- } \\
\text { based }\end{array}$ & $\begin{array}{l}\text { High } \\
\text { pric- } \\
\text { ing } \\
\text { capa- } \\
\text { bili- } \\
\text { ties }\end{array}$ & $\begin{array}{l}\text { High } \\
\text { pricing } \\
\text { cham- } \\
\text { pioning } \\
\text { behavior }\end{array}$ & $\begin{array}{l}\text { High } \\
\text { mindful- } \\
\text { ness }\end{array}$ & $\begin{array}{l}\text { Publicly } \\
\text { traded }\end{array}$ & B2B & $\begin{array}{l}\text { Large } \\
\text { firm } \\
\text { size (\# } \\
\text { employ- } \\
\text { ers) }\end{array}$ & Raw & Unique & & Cons & Cov \\
\hline 1 & 0 & - & 0 & 0 & • & & 0 & 0 & • & 0 & 0.158 & 0.014 & 0.853 & 0.809 & 0.415 \\
\hline 2 & $\bullet$ & & 0 & 0 & - & - & 0 & 0 & • & 0 & 0.165 & 0.018 & 0.881 & & \\
\hline 3 & & 0 & $\bullet$ & 0 & 0 & - & 0 & 0 & - & 0 & 0.201 & 0.020 & 0.870 & & \\
\hline 4 & - & 0 & • & 0 & $\bullet$ & & 0 & 0 & $\bullet$ & 0 & 0.190 & 0.006 & 0.875 & & \\
\hline 5 & $\bullet$ & - & • & • & • & • & & 0 & • & 0 & 0.190 & 0.006 & 0.877 & & \\
\hline 6 & - & - & - & - & • & • & - & & - & - & 0.153 & 0.037 & 0.899 & & \\
\hline 7 & 0 & • & 0 & 0 & 0 & 0 & $\bullet$ & 0 & • & 0 & 0.144 & 0.015 & 0.869 & & \\
\hline 8 & • & 0 & 0 & 0 & 0 & 0 & $\bullet$ & 0 & • & 0 & 0.139 & 0.010 & 0.858 & & \\
\hline 9 & 0 & 0 & • & 0 & • & 0 & • & 0 & • & $\bullet$ & 0.108 & 0.010 & 0.867 & & \\
\hline 10 & • & 0 & 0 & - & • & 0 & • & 0 & • & O & 0.142 & 0.008 & 0.875 & & \\
\hline 11 & - & $\bullet$ & 0 & $\bullet$ & $\bullet$ & 0 & 0 & 0 & - & 0 & 0.147 & 0.006 & 0.872 & & \\
\hline
\end{tabular}

Black circles "@" indicate the presence of antecedent conditions. White circles " $\bigcirc$ " indicate the negation of antecedent conditions. The blank cells represent ambiguous conditions

cons. consistency, cov. coverage. Frequency threshold $=2$; consistency threshold $=0.85$

other configurations hinge on the absence of high valuebased pricing, and in one configuration, value-based pricing is a "don't care" condition. Similarly, 7/11 configurations include high rationality but, again, the absence of rationality (i.e., the presence of intuition) is included in three configurations of antecedents predicting high firm performance.

\section{Configurations of antecedent conditions that are sufficient for low firm performance}

Next, we negate the outcome condition (from high firm performance into $\sim$ high firm performance, that is, low firm performance) and rerun our analysis. As Table 3 shows, this time we receive a total of 15 configurations of antecedent conditions that explain the outcome. Even though the picture changes substantially, we do not receive a complete opposite of what is presented in Table 2, which suggests a certain level of asymmetry. For example, the absence of value-based pricing is included in $8 / 15$ configurations, but firms reflected by $4 / 15$ of configurations perform value-based pricing and still end up with low firm performance.

\section{General discussion}

\section{Summary of findings and contributions}

We drew on complexity theory to develop a framework highlighting the complex interplay between pricing-related antecedents, contingency factors, and outcomes. Our research question was whether complex configurations of antecedent conditions exist that predict high firm performance. To answer our research question, we developed an IPO model of pricing that also includes firm-related contextual factors. We then analyzed the data from 557 CEOs and business owners from around the world and applied fsQCA to account for the complexity we assume to be inherent in the unique situations in which managers make pricing decisions. The results of our inquiry and analysis make important contributions to the field of pricing practices and advance the nascent method of fsQCA by applying it to a unique dataset of CEOs. Importantly, our approach enables us to identify potentially fruitful areas for further research, specifically by drawing attention to unique cases of high firm performance that one would not expect from a review of prior literature.

First, the results support the view that, by analyzing configurations instead of correlations, one can identify multiple pathways for both high and low performance. Our set-theoretic approach reveals, for example, that in large firms costand competition-based pricing combined with high pricing capabilities and high decision-making rationality are sufficient for superior performance. This set of configurations could well explain how some firms achieve higher profitability in the absence of value-based pricing, as indicated in our initial puzzle about value-based pricing in professional services. Pricing approaches are, of course, not mutually exclusive, although the literature seems to indicate that B2B firms typically struggle to understand, define, and measure customer value (Anderson et al. 2008). This leads to the following issues. First, given that multiple pricing policies are applicable in some contexts in the same firm, in which contexts do strategies report employing configurations of 


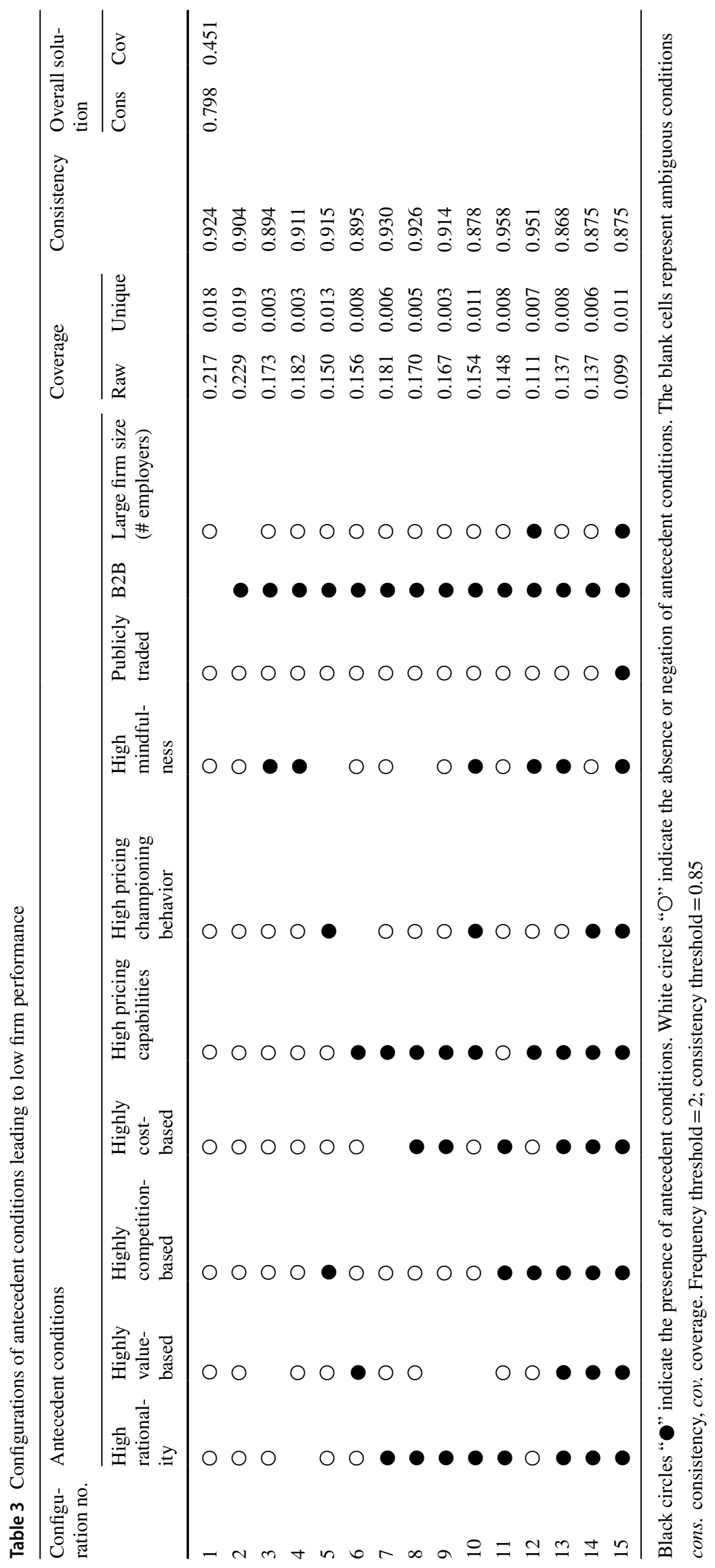


two or more pricing policies in their firms. Second, what are effective and ineffective configurations of employing configurations cost-, competition-, and value-based strategies. The design of the present study does not permit a conclusive answer, but our set-theoretic approach sheds some light on the question: for small firms, the configuration pursuit of all three pricing approaches associates with superior profitability only in the absence of rationality and pricing capabilities. We can only speculate about the reasons-for small firms, intuition, informality, and the absence of specific pricing capabilities appears to be beneficial.

Second, the findings highlight that there may be unique firm configurations that lead to superior results, which reinforces Gummesson (2008) calls to acknowledge this kind of complexity. For example, a firm doing cost-based pricing in combination with a strong level of pricing discipline can capture "low-hanging fruit" from the market by avoiding giving unnecessary discounts to the market. For example, a strong discipline in pricing realization might be more powerful than strong investments in changing a pricing orientation from cost to value (Hinterhuber and Liozu 2012a). This perspective is highly relevant for firms that adopt a price advantage strategic positioning, as done by firms Aldi, Amazon, Walmart, and Dell, and that focus on passing every cost savings on to the customer. In this configuration, adopting value-based pricing might not make sense and that these low-cost players should focus on improving their cost-based pricing excellence (Liozu 2017).

Third, this study's analysis reveals the unique combinations possible based on our dataset of 557 CEOs and business owners. Potential configurations are numerous and that it is the responsibility of each organization and its leaders to manage the relevant configuration based on their market and organizational circumstances. The configurations these leaders adopt should evolve over time based on their strategic roadmap and plans. Certain sequences of configurations could be adapted and managed strategically based on market forces. In addition, pricing is just one component of the strategic puzzle. This point reinforces that each pricing transformational journey is different and cannot be set in stone or managed in a vacuum (Liozu 2015b). Therefore, for example, a firm might adopt a centralized pricing organization with a unique reporting structure as it begins the journey. Then it might move to a decentralized model with different reporting lines once the level of pricing maturity improves (Hinterhuber and Liozu 2012b; Liozu 2014). A transformation is dynamic and needs to be agile based on market events and on internal constraints.

\section{Managerial implications}

Extant research unanimously suggests that value-based pricing has a positive effect, that competition-based pricing has a negative effect, and that, finally, cost-based pricing has a neutral effect on firm performance (Ingenbleek et al. 2003; Liozu and Hinterhuber 2013b). The unconditional recommendation that current research offers to managers that aim to increase firm performance via pricing is to implement value-based pricing (Nagle et al. 2011; Töytäri and Rajala 2015). Surveys examining the performance implications of switching from cost- to value-based pricing find that, in the case of law firms, that is, for a category of B2B services, the switch to value-based pricing actually reduces firm profitability (Seeger and Clay 2016).

The present research suggests that unconditional recommendations are misplaced and that a more fine-grained analysis of antecedent conditions is necessary and indeed possible. Our configuration-set theoretical approach suggests that there are conditions where cost-based pricing is associated with high performance: high rationality, high pricing capabilities, low pricing championing behavior, and high mindfulness (configuration 10); high rationality, high value-based pricing, high pricing capabilities, low pricing championing behavior, and low mindfulness (11). Likewise, there are numerous conditions where value-based pricing is associated with low firm performance: for example under conditions of low rationality, high pricing capabilities, and low mindfulness (configuration 11), or where all variables examined are high (high cost, competition, value-based pricing, high pricing capabilities, high championing behaviors, and high mindfulness; configuration 15).

The pictures that emerge from the current research are (a) that the optimality of any given pricing orientation is strongly dependent upon a series of antecedent conditions that pricing managers can influence (e.g., pricing capabilities, pricing championing behaviors, mindfulness), and (b) that multiple pathways to high firm performance exist. The landscape of firm performance has multiple peak points, and each requires a carefully calibrated set of antecedent conditions to be met. Driving firm performance via pricing is thus essentially not only about pricing but also about the configuration of a series of mostly controllable factors to specific pricing orientations.

\section{Limitations and future research}

Even though common method bias did not emerge as a significant problem, we acknowledge that using a perceptual measure of firm performance is not ideal. Earlier studies indicate that perceptual performance measures tend to be highly correlated with objective indicators (Dess and Robinson 1984) and are used in strategy research (Anderson and Paine 1975). Still, future research may seek to validate our study using objective performance data.

Also important is that the authors' choice of analytical method—fsQCA—does not imply that future research should 
not rely on more established quantitative approaches (regression, structural equation modeling). However, as "scientists' tools are not neutral" (Gigerenzer 1991), different methods can shape how researchers theorize about organizational issues in pricing. Thus, by applying a configurational perspective to this important managerial issue, we unveil interesting and even seemingly counterintuitive combinations of antecedent conditions, all leading to high performance, that may have gone unnoticed using other approaches. These special cases provide a springboard for future research.

Researchers need to tease out potential effects of additional context factors as implied by our conceptual model, especially environmental context factors that are not contained in the dataset we analyzed. As we have shown, multiple pathways to high financial performance exist, and factors such as environmental turbulence and competitive intensity likely drive these results.

Last, organizational design issues in pricing (such as the role of pricing teams) remain under-researched and are worth integrating into such a contingency analysis. Important insights on organizational pricing are the likely outcomes.

\section{Appendix 1: Constructs, definitions, coded items, and sources}

\begin{tabular}{|c|c|c|}
\hline Construct & Items & IR \\
\hline \multirow[t]{5}{*}{$\begin{array}{l}\text { Decision making rationality } \\
\text { Adapted from Miller (1987) } \\
C R=0.74 \\
A V E=0.49\end{array}$} & $\begin{array}{l}\text { Indicate the extent to which } \\
\text { your organization does } \\
\text { the following activities to } \\
\text { support pricing decisions. } \\
\text { (1=Does rarely to } 7=\text { Does } \\
\text { Frequently) }\end{array}$ & \\
\hline & $\begin{array}{l}\text { Applies pricing research } \\
\text { techniques such as conjoint } \\
\text { analysis and pricing/value } \\
\text { simulations to make major } \\
\text { product/service pricing } \\
\text { decisions }\end{array}$ & 0.449 \\
\hline & $\begin{array}{l}\text { Conducts brainstorming with } \\
\text { senior management groups } \\
\text { for novel solutions to pric- } \\
\text { ing problems }\end{array}$ & - \\
\hline & $\begin{array}{l}\text { Conducts formalized, system- } \\
\text { atic pricing review process } \\
\text { as part of the product/ser- } \\
\text { vice development process } \\
\text { (like Stage Gate) }\end{array}$ & 0.586 \\
\hline & $\begin{array}{l}\text { Uses staff specialists to } \\
\text { investigate and provide } \\
\text { recommendation on major } \\
\text { pricing decisions }\end{array}$ & 0.425 \\
\hline
\end{tabular}

\begin{tabular}{|c|c|c|}
\hline Construct & Items & IR \\
\hline \multirow[t]{13}{*}{$\begin{array}{l}\text { Pricing capabilities } \\
\text { Liozu and Hinterhuber (2014) } \\
C R=0.83 \\
A V E=0.57\end{array}$} & $\begin{array}{l}\text { Rate your organization rela- } \\
\text { tive to your major competi- } \\
\text { tors in terms of its capabili- } \\
\text { ties in the following areas: } \\
\text { (1= Much Worse Than } \\
\text { Competitors to } 7=\text { Much } \\
\text { Better Than Competitors) }\end{array}$ & \\
\hline & $\begin{array}{l}\text { Using pricing skills and } \\
\text { systems to respond quickly } \\
\text { to market changes }\end{array}$ & - \\
\hline & $\begin{array}{l}\text { Knowledge of competitors' } \\
\text { pricing tactics }\end{array}$ & - \\
\hline & $\begin{array}{l}\text { Doing an effective job of } \\
\text { pricing products/services }\end{array}$ & - \\
\hline & $\begin{array}{l}\text { Monitoring competitors' } \\
\text { prices and price changes }\end{array}$ & - \\
\hline & $\begin{array}{l}\text { Sticking to price list and } \\
\text { minimizing discounts }\end{array}$ & - \\
\hline & $\begin{array}{l}\text { Quantifying customers' will- } \\
\text { ingness to pay }\end{array}$ & - \\
\hline & $\begin{array}{l}\text { Measuring and quantifying } \\
\text { differential economic value } \\
\text { versus competition }\end{array}$ & - \\
\hline & $\begin{array}{l}\text { Measuring and estimating } \\
\text { price elasticity for products/ } \\
\text { services }\end{array}$ & - \\
\hline & $\begin{array}{l}\text { Designing proprietary tools } \\
\text { to support pricing decisions }\end{array}$ & 0.530 \\
\hline & $\begin{array}{l}\text { Conducting value-in-use } \\
\text { analysis or Total Cost of } \\
\text { Ownership }\end{array}$ & 0.526 \\
\hline & $\begin{array}{l}\text { Designing and conducting } \\
\text { specific pricing training } \\
\text { programs }\end{array}$ & 0.618 \\
\hline & $\begin{array}{l}\text { Developing proprietary } \\
\text { internal price management } \\
\text { process }\end{array}$ & 0.593 \\
\hline \multirow[t]{7}{*}{$\begin{array}{l}\text { Championing behavior } \\
\text { Adapted from Howell et al. } \\
\text { (2005) } \\
\text { CR }=0.84 \\
\text { AVE }=0.57\end{array}$} & $\begin{array}{l}\text { To what extent do you agree } \\
\text { or disagree with the follow- } \\
\text { ing statements about your } \\
\text { involvement with pricing } \\
\text { (1= Strongly Disagree to } \\
7=\text { Strongly Agree) }\end{array}$ & \\
\hline & $\begin{array}{l}\text { I enthusiastically promote the } \\
\text { pricing function }\end{array}$ & 0.685 \\
\hline & $\begin{array}{l}\text { I express confidence in what } \\
\text { pricing can do }\end{array}$ & 0.709 \\
\hline & $\begin{array}{l}\text { I show tenacity in overcom- } \\
\text { ing obstacles when changes } \\
\text { in pricing are needed }\end{array}$ & 0.460 \\
\hline & $\begin{array}{l}\text { I get pricing problems into } \\
\text { the hands of those who can } \\
\text { solve them }\end{array}$ & - \\
\hline & $\begin{array}{l}\text { I get key decision makers } \\
\text { involved in the pricing } \\
\text { process }\end{array}$ & - \\
\hline & I act as a champion of pricing & 0.445 \\
\hline
\end{tabular}




\begin{tabular}{|c|c|c|}
\hline Construct & Items & IR \\
\hline \multirow[t]{13}{*}{$\begin{array}{l}\text { Collective mindfulness } \\
\text { Adapted from Knight (2004) } \\
\text { based on the work of Weick } \\
\text { and Sutcliffe (2007) } \\
\mathrm{CR}=0.87 \\
\mathrm{AVE}=0.50\end{array}$} & $\begin{array}{l}\text { To what extent do you agree } \\
\text { or disagree with the follow- } \\
\text { ing statements about your } \\
\text { organization } \\
\text { (1 = Strongly Disagree to } \\
7 \text { = Strongly Agree) }\end{array}$ & \\
\hline & $\begin{array}{l}\text { Seeks input from diverse } \\
\text { sources to solve problems }\end{array}$ & - \\
\hline & $\begin{array}{l}\text { Approaches unexpected } \\
\text { events with novel solutions }\end{array}$ & - \\
\hline & $\begin{array}{l}\text { Expects employees are famil- } \\
\text { iar with tasks beyond their } \\
\text { immediate jobs }\end{array}$ & - \\
\hline & $\begin{array}{l}\text { Supports divergent view- } \\
\text { points }\end{array}$ & 0.452 \\
\hline & $\begin{array}{l}\text { Fosters a climate that encour- } \\
\text { ages open, ongoing com- } \\
\text { munication }\end{array}$ & 0.577 \\
\hline & $\begin{array}{l}\text { Pays attention to real-time } \\
\text { information }\end{array}$ & - \\
\hline & $\begin{array}{l}\text { Believes that regular updat- } \\
\text { ing, and refreshing of } \\
\text { our employees skills are } \\
\text { essential }\end{array}$ & 0.415 \\
\hline & $\begin{array}{l}\text { Strives to make ongoing } \\
\text { assessments and continual } \\
\text { updates in our operations }\end{array}$ & 0.474 \\
\hline & $\begin{array}{l}\text { Does not give up on solving } \\
\text { problems }\end{array}$ & 0.530 \\
\hline & $\begin{array}{l}\text { Encourages employees } \\
\text { to "bounce back" from } \\
\text { mistakes }\end{array}$ & 0.533 \\
\hline & $\begin{array}{l}\text { Takes steps to correct errors } \\
\text { before they worsen }\end{array}$ & 0.520 \\
\hline & $\begin{array}{l}\text { Treats failures as indicators } \\
\text { of reliability of operations }\end{array}$ & - \\
\hline \multirow[t]{6}{*}{$\begin{array}{l}\text { Cost-based pricing } \\
\text { Adapted from Ingenbleek } \\
(2007) \\
\mathrm{CR}=0.76 \\
\mathrm{AVE}=0.39\end{array}$} & $\begin{array}{l}\text { To what extent does your } \\
\text { company take into account } \\
\text { the following factors } \\
\text { when setting prices for its } \\
\text { products/services? }(1=\text { not } \\
\text { at all taken into account - } \\
7=\text { very much taken into } \\
\text { account) }\end{array}$ & \\
\hline & $\begin{array}{l}\text { Variable costs of products/ } \\
\text { services }\end{array}$ & 0.312 \\
\hline & Price necessary to break-even & 0.355 \\
\hline & $\begin{array}{l}\text { Investments in products/ } \\
\text { services }\end{array}$ & 0.440 \\
\hline & Target margin guidelines & 0.361 \\
\hline & Target return on sales levels & 0.499 \\
\hline
\end{tabular}

\begin{tabular}{|c|c|c|}
\hline Construct & Items & IR \\
\hline $\begin{array}{l}\text { Competition-based pricing } \\
\text { Adapted from Ingenbleek } \\
(2007) \\
\mathrm{CR}=0.90 \\
\mathrm{AVE}=0.59\end{array}$ & $\begin{array}{l}\text { To what extent does your } \\
\text { company take into account } \\
\text { the following factors } \\
\text { when setting prices for its } \\
\text { products/services? }(1=\text { not } \\
\text { at all taken into account - } \\
7=\text { very much taken into } \\
\text { account) }\end{array}$ & \\
\hline
\end{tabular}

Price of competitors' products/services

Competitors' current pricing $\quad 0.559$ strategy

Likelihood of competitors' strength to react

Market structure (number and 0.669 strength of competitors)

Degree of competition in the 0.648 market

Competitive advantage of competitors in the market

Value-based pricing Adapted from Ingenbleek (2007)

$\mathrm{CR}=0.87$

$\mathrm{AVE}=0.57$

To what extent does your company take into account the following factors when setting prices for its products/services? $(1=$ not at all taken into account $7=$ very much taken into account)

Advantages of the products/ services compared to competitors' products/services

Customer perceived value of the products/services

Customer willingness to pay for the unique benefits of the product/services

Balance between advantages of products/services and price

Differentiated value drivers of our products/services compared to substitutes 


\begin{tabular}{|c|c|c|}
\hline Construct & Items & IR \\
\hline \multirow{3}{*}{$\begin{array}{l}\text { Perceived relative perfor- } \\
\text { mance } \\
\text { Adapted from Ingenbleek } \\
\text { (2007); Morgan et al. } \\
\text { (2009) }\end{array}$} & \multirow{2}{*}{\multicolumn{2}{|c|}{$\begin{array}{l}\text { Please evaluate the perfor- } \\
\text { mance of your major line }\end{array}$}} \\
\hline & mance or your major line & \\
\hline & $\begin{array}{l}\text { year relative to your major } \\
\text { competitors }\end{array}$ & \\
\hline \multirow{11}{*}{$\begin{array}{l}\mathrm{CR}=0.92 \\
\mathrm{AVE}=0.81\end{array}$} & (1 = Much Worse/lower Than & \\
\hline & Competitors $-7=$ Much & \\
\hline & $\begin{array}{l}\text { Better/higher Than Com- } \\
\text { petitors) }\end{array}$ & \\
\hline & Acquisition of new customers & - \\
\hline & $\begin{array}{l}\text { Increase of sales to current } \\
\text { customers }\end{array}$ & - \\
\hline & $\begin{array}{l}\text { Growth in total sales rev- } \\
\text { enues }\end{array}$ & - \\
\hline & Absolute price levels & - \\
\hline & Pricing power in the market & - \\
\hline & Business unit profitability & 0.747 \\
\hline & Return on sales (ROS) & 0.887 \\
\hline & Return on investment (ROI) & 0.794 \\
\hline
\end{tabular}

\section{Appendix 2: Descriptive statistics, correlations, and discriminant validity of latent constructs}

\begin{tabular}{|c|c|c|c|c|c|c|c|c|c|c|}
\hline & $M$ & SD & 1 & 2 & 3 & 4 & 5 & 6 & 7 & 8 \\
\hline $\begin{array}{l}\text { 1. Value- } \\
\text { based } \\
\text { pricing }\end{array}$ & 5.51 & 1.14 & 0.76 & & & & & & & \\
\hline $\begin{array}{l}\text { 2. Com- } \\
\text { petition } \\
\text { based } \\
\text { pricing }\end{array}$ & 5.49 & 1.19 & 0.27 & 0.77 & & & & & & \\
\hline $\begin{array}{l}\text { 3. Cost- } \\
\text { based } \\
\text { pricing }\end{array}$ & 5.25 & 1.15 & 0.27 & 0.31 & 0.62 & & & & & \\
\hline $\begin{array}{l}\text { 4. Pricing } \\
\text { cham- } \\
\text { pioning } \\
\text { behav- } \\
\text { ior }\end{array}$ & 5.46 & 1.10 & 0.28 & 0.13 & 0.26 & 0.76 & & & & \\
\hline $\begin{array}{l}\text { 5. Col- } \\
\text { lective } \\
\text { mind- } \\
\text { fulness }\end{array}$ & 5.98 & 0.74 & 0.33 & 0.18 & 0.21 & 0.33 & 0.71 & & & \\
\hline $\begin{array}{l}6 . \\
\text { Ration- } \\
\text { ality }\end{array}$ & 3.04 & 1.61 & 0.21 & 0.12 & 0.31 & 0.26 & 0.13 & 0.70 & & \\
\hline $\begin{array}{l}\text { 7. Pricing } \\
\text { capa- } \\
\text { bilities }\end{array}$ & 3.98 & 1.22 & 0.25 & 0.37 & 0.21 & 0.30 & 0.18 & 0.38 & 0.76 & \\
\hline $\begin{array}{l}\text { 8. Firm } \\
\text { perfor- } \\
\text { mance }\end{array}$ & 5.18 & 1.23 & 0.24 & 0.05 & 0.12 & 0.25 & 0.24 & 0.16 & 0.27 & 0.90 \\
\hline
\end{tabular}

The bold numbers on the right represent the square root of the average variance extracted; all other numbers on the right are bivariate correlations

\section{References}

Aeppel, T. 2002. Amid weak inflation, firms turn creative to boost prices. Wall Street Journal, May 7. Retrieved from http://www. wsj.com/articles/SB1032298252917585555.

Anderson, C.R., and F.T. Paine. 1975. Managerial perceptions and strategic behavior. Academy of Management Journal 18 (4): 811-823.

Anderson, J., J. Narus, and D. Narayandas. 2008. Business market management: Understanding, creating, and delivering value, 3rd ed. Upper Saddle River, NJ: Prentice Hall.

Armstrong, J., and T. Overton. 1977. Estimating nonresponse bias in mail surveys. Journal of Marketing Research 14: 396-402.

Calantone, R., R. Garcia, and C. Dröge. 2003. The effects of environmental turbulence on new product development strategy planning. Journal of Product Innovation Management 20 (2): 90-103.

Carson, D., A. Gilmore, D. Cummins, A. O'Donnell, and K. Grant. 1998. Price setting in SMEs: Some empirical findings. Journal of Product \& Brand Management 7 (1): 74-86.

Dean, J. 1969. Pricing pioneering products. Journal of Industrial Economics 17 (3): 165-179.

Dess, G., and R. Robinson. 1984. Measuring organizational performance in the absence of objective measures: The case of the privately-held firm and conglomerate business unit. Strategic Management Journal 5 (3): 265-273.

Docters, R., R. Katz, J. Bernstein, and B. Schefers. 2010. Is the price right? Strategies for new introductions. Journal of Business Strategy 31 (3): 29-37.

Dutta, S., M. Bergen, D. Levy, M. Ritson, and M. Zbaracki. 2002. Pricing as a strategic capability. MIT Sloan Management Review 43 (3): 61-66.

Dutta, S., M.J. Zbaracki, and M. Bergen. 2003. Pricing process as a capability: A resource-based perspective. Strategic Management Journal 24 (7): 615-630.

Eggert, A., W. Ulaga, P. Frow, and A. Payne. 2018. Conceptualizing and communicating value in business markets: From value in exchange to value in use. Industrial Marketing Management 69: 80-90.

Elbanna, S., and J. Child. 2007. Influences on strategic decision effectiveness: Development and test of an integrative model. Strategic Management Journal 28 (4): 431-453.

Eling, K., A. Griffin, and F. Langerak. 2014. Using intuition in fuzzy front-end decision-making: A conceptual framework. Journal of Product Innovation Management 31 (5): 956-972.

Eling, K., F. Langerak, and A. Griffin. 2015. The performance effects of combining rational and intuitive approaches in making new product idea evaluation decisions. Creativity and Innovation Management 24 (3): 464-477.

Evans, J.S.B.T. 2008. Dual-processing accounts of reasoning, judgment, and social cognition. Annual Review of Psychology 59: 255-278.

Feurer, S., E. Baumbach, and A. Woodside. 2016. Applying configurational theory to build a typology of ethnocentric consumers. International Marketing Review 33 (3): 1-48.

Feurer, S., M.C. Schuhmacher, and S. Kuester. 2018. How pricing teams develop effective pricing strategies for new products. Journal of Product Innovation Management. https://doi.org/10.1111/ jpim.12444. 
Fiss, P.C. 2011. Building better causal theories: A fuzzy set approach to typologies in organization research. Academy of Management Journal 54 (2): 393-420.

Galbraith, J.R. 1974. Organization design: An information processing view. Interfaces 4 (3): 28-36.

Gallagher, T., M.D. Mitchke, and M.C. Rogers. 2005. Profiting from spare parts. McKinsey Quarterly, February. Retrieved from https ://pdfs.semanticscholar.org/aa41/f179d2f3579438454bc27a793 96cd20eff49.pdf.

Gatignon, H., and J.-M. Xuereb. 2016. Strategic orientation of the firm and new product performance. Journal of Marketing Research 34 (1): 77-90.

Gigerenzer, G. 1991. From tools to theories: A heuristic of discovery in cognitive psychology. Psychological Review 98 (2): 254-267.

Gummesson, E. 2008. Extending the service-dominant logic: From customer centricity to balanced centricity. Journal of the Academy of Marketing Science 36 (1): 15-17.

Hinterhuber, A. 2015. Violations of rational choice principles in pricing decisions. Industrial Marketing Management 47 (May): 65-74.

Hinterhuber, A. 2017. Value quantification capabilities in industrial markets. Journal of Business Research 76: 163-178.

Hinterhuber, A., and S.M. Liozu. 2012a. Is it time to rethink your pricing strategy? MIT Sloan Management Review 53 (4): 69-77.

Hinterhuber, A., and S.M. Liozu. 2012b. Innovation in pricing: Contemporary theories and best practices. Abingdon: Routledge.

Hoeffler, S. 2003. Measuring preferences for really new products. Journal of Marketing Research 40 (4): 406-421.

Homburg, C., O. Jensen, and A. Hahn. 2012. How to organize pricing? Vertical delegation and horizontal dispersion of pricing authority. Journal of Marketing 76 (5): 49-69.

Howell, J., C. Shea, and C. Higgins. 2005. Champions of product innovations: Defining, developing, and validating a measure of champion behavior. Journal of Business Venturing 20 (5): 641-661.

Hultink, E.J., A. Griffin, H.S.J. Robben, and S. Hart. 1998. In search of generic launch strategies for new products. International Journal of Research in Marketing 15 (3): 269-285.

Hultink, E.J., S. Hart, H.S.J. Robben, and A. Griffin. 2000. Launch decisions and new product success: An empirical comparison of consumer and industrial products. Journal of Product Innovation Management 17 (1): 5-23.

Ilgen, D.R., J.R. Hollenbeck, M. Johnson, and D. Jundt. 2005. Teams in organizations: From input-process-output models to IMOI models. Annual Review of Psychology 56: 517-543.

Ingenbleek, P. 2007. Value-informed pricing in its organizational context: Literature review, conceptual framework, and directions for future research. Journal of Product \& Brand Management 16 (7): $441-458$

Ingenbleek, P., M. Debruyne, R.T. Frambach, and T.M.M. Verhallen. 2003. Successful new product pricing practices: A contingency approach. Marketing Letters 14 (4): 289-305.

Ingenbleek, P.T.M., R.T. Frambach, and T.M.M. Verhallen. 2010. The role of value-informed pricing in market-oriented product innovation management. Journal of Product Innovation Management 27 (7): 1032-1046

Ingenbleek, P.T.M., R.T. Frambach, and T.M.M. Verhallen. 2013. Best practices for new product pricing: Impact on market performance and price level under different conditions. Journal of Product Innovation Management 30 (3): 560-573.

Ingenbleek, P.T.M., and I.A. van der Lans. 2013. Relating price strategies and price-setting practices. European Journal of Marketing 47 (1): $27-48$.

Kleinschmidt, E.J., and R.G. Cooper. 1991. The impact of product innovativeness on performance. Journal of Product Innovation Management 8 (4): 240-251.
Knight, A. (2004). Measuring collective mindfulness and exploring its nomological network. Unpublished dissertation, University of Maryland, College park, MD

Lambrecht, A., K. Seim, N. Vilcassim, A. Cheema, Y. Chen, G.S. Crawford, et al. 2012. Price discrimination in service industries. Marketing Letters 23 (2): 423-438.

Lancioni, R. 2005. Pricing issues in industrial marketing. Industrial Marketing Management 34 (2): 111-114.

Langer, E. 1989. Mindfulness. Reading, MA: Addison-Wesley.

Langer, E. 1997. The power of mindful learning. Reading, MA: Addison-Wesley.

Liozu, S.M. 2014. Where should pricing report into? Journal of Professional Pricing Q3: 16-19.

Liozu, S.M. 2015a. Pricing superheroes: How a confident sales team can influence firm performance. Industrial Marketing Management 47: 26-38.

Liozu, S.M. 2015b. The pricing journey: The organizational transformation toward pricing excellence. Stanford, CA: Stanford University Press.

Liozu, S.M. 2017. A reality check on cost-based pricing and valuebased pricing. Journal of Professional Pricing Q2: 20-24.

Liozu, S., and A. Hinterhuber. 2013a. CEO championing of pricing, pricing capabilities and firm performance in industrial firms. Industrial Marketing Management 42 (4): 633-643.

Liozu, S., and A. Hinterhuber. 2013b. Pricing orientation, pricing capabilities, and firm performance. Management Decision 51 (3): 594-614.

Liozu, S., and A. Hinterhuber. 2014. Pricing capabilities: The design, development and validation of a scale. Management Decision 52 (1): 144-158.

Lowe, B., and F. Alpert. 2010. Pricing strategy and the formation and evolution of reference price perceptions in new product categories. Psychology \& Marketing 27 (9): 846-873.

Miller, C.C., and R.D. Ireland. 2005. Intuition in strategic decision making: Friend or foe in the fast-paced 21 st century? The Academy of Management Executive 19 (1): 19-30.

Miller, D. 1987. Strategy making and structure: Analysis and implications for performance. Academy of Management Journal 30 (1): 7-32.

Monroe, K.B., and A.J. Della Bitta. 1978. Models for pricing decisions. Journal of Marketing Research 15 (3): 413-428.

Morgan, N.A., D.W. Vorhies, and C.H. Mason. 2009. Market orientation, marketing capabilities, and firm performance. Strategic Management Journal 30 (8): 909-920.

Nagle, T., J. Hogan, and J. Zale. 2011. The strategy and tactics of pricing: A guide to growing more profitably, 5th ed. Upper Saddle River, NJ: Prentice Hall.

Ordanini, A., A. Parasuraman, and G. Rubera. 2014. When the recipe is more important than the ingredients: A qualitative comparative analysis (QCA) of service innovation configurations. Journal of Service Research 17 (2): 134-149.

Oxenfeldt, A.R. 1973. A decision-making structure for price decisions. Journal of Marketing 37 (1): 48-53.

Podsakoff, P.M., S.B. MacKenzie, J.-Y. Lee, and N.P. Podsakoff. 2003. Common method biases in behavioral research: A critical review of the literature and recommended remedies. Journal of Applied Psychology 88 (5): 879-903.

Ragin, C.C. 2000. Fuzzy-set social science. Chicago, IL: University of Chicago Press.

Ragin, C.C. 2005. From fuzzy sets to crisp truth tables. Working Paper, University of Arizona, Tucson, AZ.

Ragin, C.C. 2008, September. User's guide to fuzzy-set/qualitative comparative analysis. Arizona: Department of Sociology, University of Arizona.

Ragin, C.C. 2009. Qualitative comparative analysis using fuzzy sets (fsQCA). In Configurational comparative methods: Qualitative 
comparative analysis (QCA) and related techniques, ed. B. Rihoux and C.C. Ragin, 87-121. Thousand Oaks, CA: Sage.

Sadler-Smith, E., and E. Shefy. 2004. The intuitive executive: Understanding and applying "gut feel" in decision-making. Academy of Management Executive 18 (4): 76-91.

Seeger, E.A., and T.S. Clay. 2016. Law firms in transition: An Altman Weil flash survey. Newtown Square, PA: Altman Weil.

Shapiro, C., and H.R. Varian. 1998. Versioning: The smart way to sell information. Harvard Business Review 76 (6): 106-114.

Siemsen, E., A. Roth, and P. Oliveira. 2010. Common method bias in regression models with linear, quadratic, and interaction effects. Organizational Research Methods 13 (3): 456-476.

Simsek, Z., C. Heavey, and J.J.F. Veiga. 2010. The impact of CEO core self evaluation on the firm's entrepreneurial orientation. Strategic Management Journal 31 (1): 110-119.

Smith, G.E. 1995. Managerial pricing orientation: The process of making pricing decisions. Pricing Strategy and Practice 3 (3): 28-39.

Töytäri, P., and R. Rajala. 2015. Value-based selling: An organizational capability perspective. Industrial Marketing Management 45: 101-112.

Tushman, M.L., and D.A. Nadler. 1978. Information processing as an integrating concept in organizational design. Academy of Management Review 3 (3): 613-624.

Urban, G.L., B.D. Weinberg, and J.R. Hauser. 1996. Premarket forecasting of really-new products. Journal of Marketing 60 (1): $47-60$.

Urry, J. 2005. The complexity turn. Theory, Culture \& Society 22 (5): $1-14$.

Venkatraman, N. 1989. The concept of fit in strategy research: Toward verbal and statistical correspondence. Academy of Management Review 14 (3): 423-444.

Verhoef, P.C., and P.S.H. Leeflang. 2009. Understanding the marketing department's influence within the firm. Journal of Marketing 73 (2): 14-37.
Weick, K., and K. Sutcliffe. 2007. Managing the unexpected: Resilient performance in an age of uncertainty. San Francisco, CA: Jossey-Bass.

Weick, K., K. Sutcliffe, and D. Obstfeld. 1999. Organizing for high reliability: Processes of collective mindfulness. Research in Organizational Behavior 21: 81-123.

Woodside, A.G. 2014. Embrace $\bullet$ perform $\bullet$ model: Complexity theory, contrarian case analysis, and multiple realities. Journal of Business Research 67 (12): 2495-2503.

Woodside, A.G. 2015. The general theory of behavioral pricing: Applying complexity theory to explicate heterogeneity and achieve highpredictive validity. Industrial Marketing Management 47: 39-52.

Woodside, A.G., A. Schpektor, and X. Xia. 2013. Triple sense-making of findings from marketing experiments using the dominant variable based-logic, case-based logic, and isomorphic modeling. International Journal of Business and Economics 12 (2): 131-153.

Wu, P.-L., S.-S. Yeh, T.-Ch. Huan, and A.G. Woodside. 2014. Applying complexity theory to deepen service dominant logic: Configural analysis of customer experience-and-outcome assessments of professional services for personal transformations. Journal of Business Research 67 (8): 1647-1670.

Zbaracki, M.J., and M. Bergen. 2010. When truces collapse: A longitudinal study of price-adjustment routines. Organization Science 21 (5): 955-972.

Publisher's Note Springer Nature remains neutral with regard to jurisdictional claims in published maps and institutional affiliations. 